\title{
Pricing strategies and competition in the mobile broadband market ${ }^{t}$
}

\author{
Joan Calzada* and Fernando Martínez-Santos ${ }^{+}$
}

\begin{abstract}
May 2016
Abstract

This paper analyzes mobile broadband plan prices from 37 countries between 2011 and 2014. Mobile network operators typically commercialize usage-based plans that include an access fee, a usage allowance (number of GB included in the tariff plan), and a penalty system should consumers exceed the contracted allowance. Our empirical model shows that the prices of these plans are lower than those of unlimited contracts, and that they depend on the type of penalty that is used. The prices also reflect service characteristics, including the technology provided, the download speed, and telephone call allowances. Plans that bundle mobile broadband plans with smartphone devices have longer contract duration and may be more expensive than plans that only include a SIM card. Specifically, broadband service plans are priced higher when they include an iPhone or a Samsung smartphone. The paper also discusses the impact of market structure and entry regulation on prices.
\end{abstract}

Keywords: Telecommunications, Mobile Broadband, Price Discrimination, Smartphones, Competition, Regulation.

JEL: L51, L86, L96.

\footnotetext{
${ }^{ \pm}$We thank two anonymous referees as well as Joan Ramon Borrell, Xavier Fageda, Lukasz Grzybowski, Teodosio Pérez-Amaral and Carlos Velasco for their useful comments and suggestions. We also thank seminar participants at the Workshop on Telecommunications Economics 2015 (Barcelona) and ITS 2015 (Madrid). This research has received financial support from the Spanish Ministry of Economics and Competitiveness (ECO2015-69193R, MINECO/FEDER, UE) and the Catalan Government (SGR2009-1066).

* Joan Calzada, Departament de Política Econòmica, Universitat de Barcelona, Avinguda Diagonal 690, 08520 Barcelona. Email: calzada@ub.edu.

+ Corresponding author: Fernando Martínez-Santos, Competition and Markets Authority and Universitat de Barcelona. Departament de Política Econòmica, Avinguda Diagonal 690, 08520 Barcelona. Email: fmartinezsantos@hotmail.com.
} 


\section{Introduction}

This paper analyzes how mobile operators set prices for their broadband plans at a time when mobile services are experiencing extraordinary growth worldwide. Indeed, according to the International Telecommunication Union (ITU), in 2015 the penetration of mobile lines was 97\% (more than 7 billion subscribers) and the penetration of mobile broadband was $47 \%$. The parallel development of mobile content and mobile applications has led to major changes in the population's communication habits. In addition to making phone calls, consumers use smartphones to take part in video-conferences, navigate webpages, share files (including photos and high definition videos), and play online games. As a result, a sizable part of the revenues generated by operators today are originated by data traffic rather than by phone calls and SMS messages.

The transformation of the mobile market has led operators to introduce complex tiered pricing schemes with the objective of improving traffic management and of extracting the maximum surplus from consumers. Under tiered pricing systems, operators offer menus of plans with different monthly data allowances at fixed rates. The plans include overage charges should consumers exceed data caps. They also offer minute allowances for making phone calls and they might specify the speed of the service. Some operators also offer unlimited usage-plans for heavy users of broadband services, although they are much less frequent. Finally, many operators offer plans that bundle smartphone devices and the broadband service.

The use of this pricing structure has generated a major debate in the sector that has found an audience with antitrust authorities (Lyons, 2013). While some consumer associations and large content providers have warned that monthly consumption limits create artificial scarcity and allow operators to reduce future network upgrades, supporters of broadband usage pricing claim that the policy brings prices into line with the intensity of use and shifts more network costs onto heavier users. Indeed, with a flat rate all users contribute equally to meet network costs, although heavier consumers use more of the network capacity. By contrast, usage-based tariffs can reduce the cost of lighter users and promote Internet adoption. Moreover, they alleviate network congestion and induce an efficient use of broadband capacity. The objective of this paper is to contribute to this debate by empirically analyzing the drivers of operators' pricing strategies and to understand the significant price differences that exist across countries (Fig. 1).

Our study draws on a rich dataset offered by the Federal Communications Commission (FCC) that contains 2,909 plans released by mobile network operators (MNOs) in 37 countries around the globe during the period 2011-2014. We construct a variable for the average monthly price of each plan that includes activation costs, promotions and rebates. We then use multivariate techniques to estimate a price equation that takes into account several characteristics of the plans, including volume allowances (gigabytes), overage charges, download speeds, voice minute allowances and the purchase of smartphones. 
Figure 1: Average price (\$PPP) for smartphone plans with a volume allowance between 1 and 5 GB and unlimited voice minutes, year 2013.

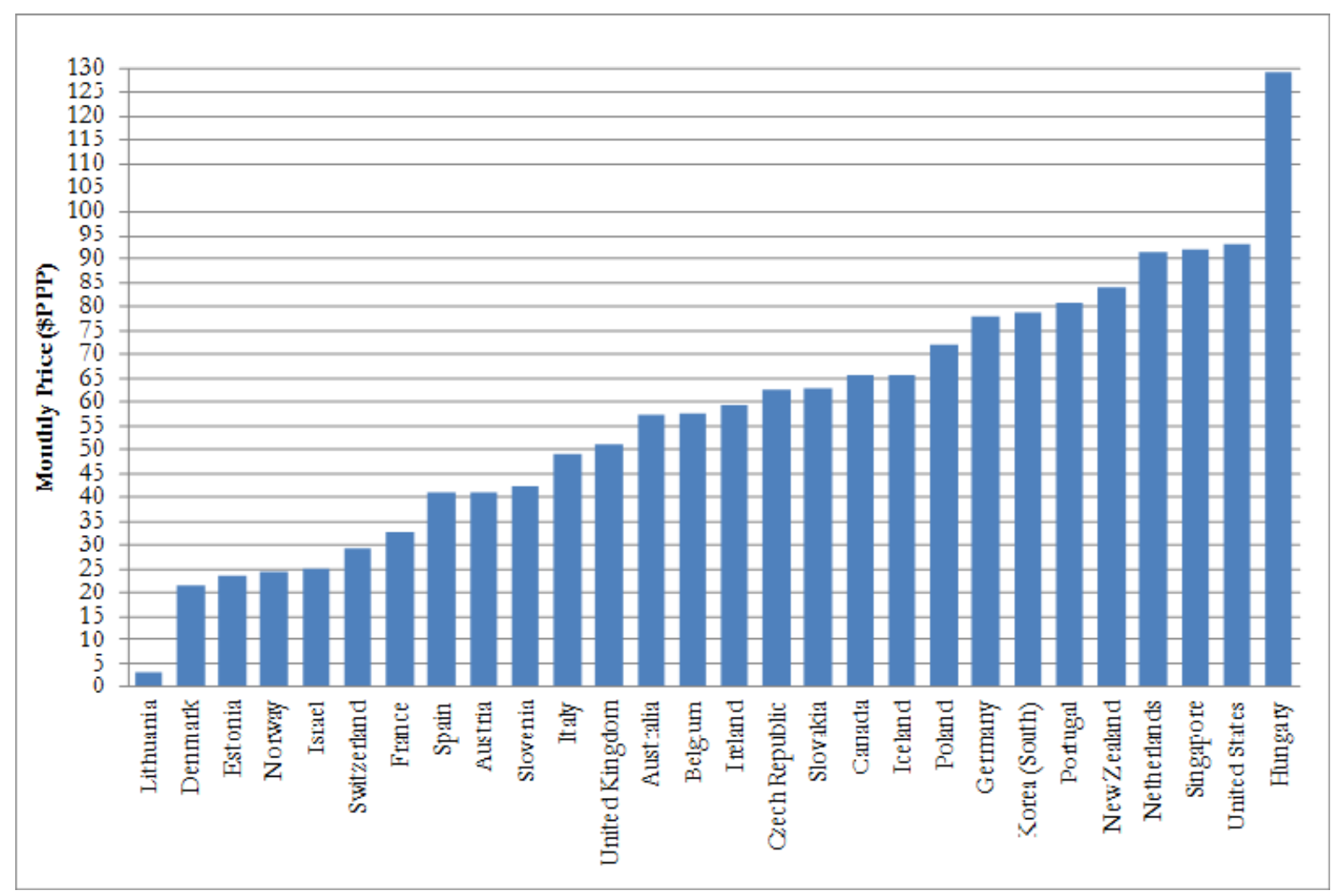

Note: The monthly all-inclusive price reflects the average price per month, including rebates and other fees, but excluding the cost of the device.

Source: FCC, 2015.

The heterogeneity in consumer preferences for the broadband service, telephone calls and smartphones has led mobile operators to adopt multi-tier pricing schemes to segment consumers (second degree price discrimination). Operators offer a menu of plans with different volume allowances and set volume discounts to promote consumption. We show that a one-gigabyte increase in the data cap would have a positive impact of around 9\% on the average monthly price paid by the customer, but that plans with large volume allowances charge lower prices per gigabyte. Although most mobile plans limit data traffic to a few gigabytes, some operators offer unlimited data plans at significantly higher prices to attract heavy users. Plans are also differentiated in terms of the speed of the service. A $10 \mathrm{Mbps}$ increase in download speed results, on average, in around a $2 \%$ rise in prices. Interestingly, while for fixed broadband plans the main segmentation strategy is that of download speed, mobile broadband plans are characterized by volume allowances due to the constraints imposed by the technology.

Operators usually apply different types of penalties to consumers that exceed the contracted volume allowance. All consumers pay the same flat rate for the service up to the contracted data cap, but heavier users have to pay a penalty when they consume volume beyond this cap. The penalty might constitute a reduction in the speed of the service or the interruption of the service 
until the next month. Often, however, consumers are switched to a new volume allowance or are billed an overage charge for each additional gigabyte consumed. Our analysis has found that all penalties have a similar impact on the average monthly price paid by consumers, although in the case of monetary penalties heavy users have to pay a supplement when they exceed the data cap.

Most plans bundle the broadband service with telephone calls. We measure the effect of the inclusion of voice minutes in the price of the plan; however, due to data limitations, we are unable to observe if the price of telephone calls in such bundles is lower than that charged by plans that only offer stand-alone voice services. It should be stressed that most operators today employ a tier scheme for telephone calls, as opposed to the pay-per-use schemes in operation a few years ago. The plans no longer distinguish between on-net and off-net calls, or between fixed-to-mobile and mobile-to-mobile calls.

The paper also considers the possibility offered to consumers of acquiring a smartphone along with a broadband service contract. Consumers can pay upfront for a smartphone at the beginning of the contract, or they can pay an extra charge in their monthly bill during the life of the contract. In either case consumers pay less for the smartphone than if they buy it directly from an independent dealer. In spite of this, our empirical model shows that the discounts offered by operators for smartphones are in part offset by charging higher prices for broadband services. We also show that the average monthly price for the broadband service is significantly more expensive if the plan includes iPhone and Samsung devices. By contrast, plans that bundle the broadband service with smartphones from other brands do not show a significant price difference with respect to SIM-only plans. This result suggests that operators segment consumers according to their willingness to pay for a particular brand of smartphone (third degree price discrimination).

The last part of the paper examines how competition intensity and regulation affect the operators' commercialization strategies. To do so, we consider a sub-sample of 20 EU countries for which we have obtained additional information about their market characteristics from other sources such as the European Commission Directorate General for Communications Networks (DG-CONNECT). In recent years, European countries have granted a restricted number of 3G and 4G licenses, which allow operators to offer broadband services. Moreover, national regulatory bodies determine the conditions according to which mobile virtual network operators (MVNOs) can access the spectrum of MNOs. Our analysis shows that market competition and the presence of MVNOs are associated with lower broadband prices. We also analyze the effects of the Mobile Termination Rates (MTRs) that mobile operators charge their rivals for terminating telephone calls. In this case, we find no evidence that MTRs have affected retail prices. We argue that this may be a consequence of the smaller weight that telephone calls have today in the broadband plans due to changes in consumption habits, and also to the small size of MTRs.

The rest of the paper is structured as follows. Section 2 reviews the economic literature that analyzes the broadband market and the operators' pricing strategies. Section 3 presents our model. Section 4 describes the dataset used in the study. Section 5 shows the results and discusses their implications. Section 6 examines the effects of competition and regulation on prices. Finally, Section 7 concludes. 


\section{Literature review}

Our research contributes to the empirical literature analyzing broadband Internet prices in the telecommunications market. Several papers have examined the effect of inter- and intra-platform competition on the adoption of fixed broadband (Cambini and Jiang, 2009; Bouckaert et al., 2010; Pereira and Ribeiro, 2010; Briglauer et al., 2013; Gruber and Koutroumpis, 2013; Grzybowski and Dauvin, 2014), and others have analyzed the effects of regulating termination charges and the unbundling of the local loop on investments (Grajek and Röller, 2012; Nardotto et al., 2015; Bacache et al., 2013).

The literature analyzing the adoption of mobile broadband is scarce. Westlund and Bohlin (2008) analyze mobile Internet adoption in Sweden and highlight that user-friendliness and transmission speed are important determinants of the development of the service. Lee et al. (2011) employ a logistic diffusion model to analyze the drivers of broadband expansion in a group of 26 OECD countries in the period 2003-2008. They find that standardization policies and population density are essential factors for the initial diffusion of the service, and that fixed and mobile broadband services are complementary in OECD countries. Srinuan et al. (2012a) use a binomial logit regression model and find that in Thailand the age, region of residence and availability of fixed telephony are significant drivers of mobile internet access. Finally, Srinuan et al. (2012b) consider a panel dataset of Finnish households in 2009, and use a multinomial logit model to examine which household characteristics explain Internet adoption.

The analysis of broadband prices has focused mainly on the fixed broadband service. Wallsten and Riso (2010) examine the prices of broadband plans in a group of 30 OECD countries and find that between 2007 and 2009 downstream speed had a positive effect on prices; that plans with bit caps were on average cheaper than unlimited plans with contracts; and, that plans with contracts were typically less expensive than those without. Greenstein and McDevitt (2011) analyze the economic value created by the diffusion of broadband Internet access provided via xDSL and cable modem in the United States. While they do not have direct information on prices, they are able to create a price index that adjusts the price to progressive improvements in service quality between 2004 and 2009. Calzada and Martínez-Santos (2014) analyze the determinants of broadband prices in a group of 15 EU countries between 2008 and 2011. They show that the prices were determined primarily by access regulations and service characteristics, including the technology used to provide the service and the bundling of the broadband service with other services such as television. Finally, Nevo et al. (2016) employ high-frequency usage data from a group of around 55,000 subscribers in the US to estimate demand for a residential fixed broadband service. They use their model estimates to evaluate the welfare implications of usage-based pricing. Very few papers have analyzed how mobile operators set the prices of broadband plans. Srinuan et al. (2013) examine the prices of wireless communications in Thailand and demonstrate the role played by demand characteristics in the development of new plans, and Haucap et al. (2014) analyze the effect of tariff diversity on broadband uptake using a data set of fixed and mobile broadband plans via USB modem devices. 
There is also a relevant stream of theoretical literature that has analyzed the pricing structures of firms in different markets (Tirole, 1988; Wilson, 1993). A basic assumption of these papers is that consumers are rational decision makers who choose the tariff that maximizes their surplus. This hypothesis has been empirically verified in several recent papers for the telecommunications market. Miravete (2003) shows that when subscribing to a particular plan consumers are guided by their expectations of future telephone use. Moreover, consumers learn from their mistakes and switch tariffs to minimize their expenses. In a related paper, Miravete and Palacios-Huerta (2014) find that telephone subscribers do not make permanent mistakes, and explain that inertia (or inattention) is likely caused by a rational decision since consumers actively engage in tariff switching in order to reduce their costs. Additionally, recent theoretical papers have analyzed how the pricing structures established by operators can affect consumers' usage decisions and transform the utility offered by firms (Ascarza et al., 2010; Leider and Sahin, 2014). The underlying assumption in these models is that consumers make mistakes when making their decisions because they are uncertain as to how much they are likely to consume of the service and about the utility they can obtain. In this context, it has been shown that pricing structures influence the types of mistake consumers make (Lambrecht et al., 2007).

Recent papers have examined the interaction between mobile operators and other players that intervene in the telecommunications market, including content providers and smartphone manufacturers. Economides and Hermalin (2015) analyze why carriers opt to commercialize volume-metered plans. It is usually claimed that volume caps are used to segment consumers and to alleviate congestion externalities. But this paper shows that telecommunication operators can also use the caps to increase competition between content providers. Consumption restrictions lead content providers to lower their prices and this allow telecommunication operators to attract more consumers. Another group of papers have analyzed the effect of exclusive contracts with handset manufacturers. Zhu et al. (2015) examine the welfare effects of Apple's exclusivity, while Sinkinson (2014) analyzes the effects of exclusive smartphone contracts using a monthly market-level dataset of US consumers for the period 2008-2010.

\section{Empirical model}

We examine the prices of mobile broadband using a dataset containing information for 2,909 plans collected by the FCC between 2011 and 2014 from 37 countries. Our aim is to analyze how MNOs set their prices in order to increase their customer base and extract the maximum surplus from them. Our model is based on a reduced-form equation in which we consider prices to be determined by the interaction of supply and demand in the telecommunications market. The equilibrium price function that we estimate reflects a bundle of attributes that generate some consumer utility. We also consider that the prices can be affected by the characteristics of the operators and the market conditions.

We estimate a model for the average monthly price of mobile broadband plans, Price moit, where $m$ is the plan offered by the operator, $o$ is the operator, $i$ is the country, and $t$ is the year. Specifically, we consider the pricing equation in (1), which includes several variables that capture the attributes of the operators' multi-tier schemes as well as other variables that reflect the operators' characteristics and the market structure. Country $\left(\delta_{i}\right)$ and year $\left(\eta_{t}\right)$ fixed effects are 
included to control for unobserved heterogeneity across countries and years. Finally, $e_{\text {moit }}$ represents the disturbance term.

$$
\begin{aligned}
& \log \left(\text { Price }_{\text {moit }}\right)=a_{0}+a_{1} \text { LimitedDaa }_{\text {moit }}+a_{2} \text { Penalty }{ }_{\text {moit }}+a_{3} \text { Volume }_{\text {moit }}+a_{4} \text { Volume }_{\text {moit }}^{2}+a_{5} \text { Speed }_{\text {moit }}+a_{6} \text { Technology }_{\text {moit }} \\
& +a_{7} \text { LimitedVớe }{ }_{\text {moit }}+a_{8} \text { MinVoice } \text { moit }_{9}+a_{9} \text { Smartphone } \text { moit }_{10}+a_{10} \text { Historical }_{\text {moit }}+a_{11} \text { NPlans }_{\text {moit }}+\delta_{i}+\eta_{t}+\mathrm{e}_{\text {moit }}
\end{aligned}
$$

The price of a plan is the average monthly price paid by consumers during the period in which contracts are active. The bulk of the price is the monthly tariff, but we also consider temporary monthly promotions offered at the beginning of the contract, rebates (refunds) and non-recurring costs, such as activation fees. Equation (2) shows that the average monthly price is constructed as the sum of the promotional tariff paid during the months of the promotion, plus the regular tariff paid during the remaining months in which consumers are subscribed to the plan, plus activation costs paid at the beginning of the contract, and rebates. The existence of activation costs and rebates implies that the average monthly price depends on the number of months consumers are subscribed to the plan, which may differ from the duration specified in the contract itself. Taking this into account, in the general specification of the model we assume that consumers are subscribed to a plan for 24 months, which is the median duration of the contracts in our sample (representing a $60 \%$ of all the plans). It should be clarified however that the activations costs and rebates represent just a fraction of the costs borne by customers. For this reason, the results of our analysis do not vary greatly when we consider permanence periods of 12, 36 or 48 months. ${ }^{1}$ Yet, in order to examine whether the tariff design depends on the duration of the contracts we also present the results of separate regressions considering only 12- and 24month plans.

Price $_{\text {moit }}=\frac{\text { Promotion x Months Promotion }+ \text { Tariff } x \text { Months Without Promotion+ Fees - Rebates }}{24 \text { months }}$

We consider that operators commercialize both unlimited usage plans and three-part tariff plans. In this latter case, the tariff includes an access fee, a usage allowance (number of GB that consumers can use for free), and a penalty system should the consumer exceed the contracted allowance. ${ }^{2}$ In order to capture these options, the pricing model includes the dummy variable Limited Data, which distinguishes between usage-based and unlimited usage plans. This variable takes a value of one for three-part tariffs (limited usage) and a value of zero otherwise.

\footnotetext{
${ }^{1}$ Results are available from the authors upon request. Also note that in the case of fixed broadband plans, the average duration of the contracts in the EU is 26 months (European Commission, 2011).

${ }^{2}$ According to Lyons (2013), three-tiered pricing plans were first introduced in the US by AT\&T in December 2010. These plans establish volume allowances and a per-gigabyte overage charge. Verizon Wireless adopted a similar pricing scheme in 2011.
} 
The penalties imposed on the consumers that exceed the volume allowances can take the form of pay-per-unit charges (per megabyte) or they might oblige consumers to switch to a new usage allowance. Penalties may also involve a reduction in speed or even the suspension of the service until the beginning of the following month. We have created the following four dummy variables to capture the characteristics of the penalties: End Service whereby the consumer cannot access the Internet once the allowance has been exceeded (an option used in only a few countries, including Belgium and Korea); Speed Reduction whereby the download speed is greatly reduced (e.g., 128 kbps), thus preventing consumers from using applications that require higher speeds, such as watching videos; Pay-as-you-go whereby consumers are obliged to pay a price per each additional unit of volume (megabyte/kilobyte); and, finally, New Allowance whereby consumers are moved to a new allowance that gives them access to a greater number of gigabytes, but at a higher price.

Note that both Pay-as-you-go and New Allowance are 'overage charges' and might result in an unexpected increase in the bill paid by the consumer ('bill shock'). Such a situation arises when consumers have a poor understanding of their contract conditions or when they are uncertain about their future consumption. Operators may also shroud these overage charges in order to make consumers pay more (Gabaix and Laibson, 2006). Our data set only contains the information included in the operators' plans and, therefore, we cannot determine the impact the penalties have on the final bill paid by consumers or the circumstance under which they switch to a new plan (Miravete and Palacios-Huerta, 2014).

In the case of plans with three-part tariffs, the variable Volume is defined as the volume allowance (in gigabytes) that restricts the data that can be downloaded by consumers each month. Volume caps are introduced in the price equation in a non-linear way, since we expect the price per unit of volume (gigabytes) to decrease with the allowance. The operators' offer of usage-based plans can be made for various reasons. Volume caps are a second degree price discrimination mechanism, which allow operators to charge higher prices to consumers that use the service more intensively, but they can also help operators optimize the use of the network and so reduce congestion. As explained in Section 2, Economides and Hermalin (2014) have shown that operators may also use volume caps to appropriate surplus from content providers by employing the following mechanisms: if volume caps are binding (End Service, Speed Reduction), consumers perceive the contents and applications of different providers as substitutes. This, in turn, increases the competitive pressures on the content providers, who respond by lowering their prices. In this case, mobile operators can capture the surplus gained by consumers by raising the prices of their plans. If caps are permeable (Pay-as-you-go, New Allowance), then they act as a disguised two-part tariff and the additional fee charged by operators acts as an excise tax that results in content providers cutting their prices.

Broadband prices might reflect other aspects related to service quality. Download Speed is the maximum speed at which the broadband service can operate. Speed tiers segment consumers by taking into account their willingness to pay for quality and their interest for using dataconsuming applications. Note, however, that many MNOs do not state the download speed on their websites. This might be because most of them use the same technology or because they are 
unable to guarantee the quality of the service. ${ }^{3}$ In the case of fixed broadband plans, by contrast, operators use different provision technologies (xDSL, cable and fiber) and can price discriminate consumers in terms of the speed offered (Calzada and Martínez-Santos, 2014).

The main factor accounting for download speed is transmission technology. For each generation of mobile telephony, the ITU has approved technological standards (e.g., GSM, WCDMA, UMTS, HSPA, LTE), which have to meet a number of technical requirements, for example, in relation to download speed and the latency of the service. In the period we analyze, mobile operators used several standards and we have grouped them according to 3G, 3.5/3.75G, and 4G technologies and created a dummy variable for each. ${ }^{4}$ We use the Technology variables to analyze if operators are able to charge higher prices for $4 \mathrm{G}$ plans than for the other technologies, or if competition forces them to upgrade the quality of the service at no extra cost.

Many plans combine data allowances with voice minute and/or text message allowances. The popularization of smartphones has greatly modified the way in which people use telephone services. In recent years, a large part of voice traffic has been substituted by such applications as WhatsApp or Line for messages and Skype for voice. Operators have reacted to this situation by modifying the way they bill telephone calls. Some plans offer mobile broadband exclusively, but most include voice minute and/or text message allowances. We capture this situation in our model by including the dummy variable Limited Voice Minutes, which takes a value of one if the plan includes voice minute allowances and zero if the plan includes unlimited phone calls. For plans with voice minute allowances, the variable Minutes of Voice reflects the minutes of the cap. According to the FCC (2015), in some countries, operators use phone calls to crosssubsidize their data plans. Unfortunately, we are unable to analyze this strategy as we have no information about plans that only offer telephone calls.

Our data set also allows us to determine whether a plan offers no more than a SIM card or whether it also includes the purchase of a smartphone. Consumers that purchase a smartphone from the mobile operator usually have to choose between paying for the smartphone upfront or paying a monthly tariff that embeds the cost of the smartphone over the duration of the contract. In order to determine how the purchase of the smartphone affects the price of the service, we include four dummies for Smartphone in the price function. One of the dummies represents SIM card only plans, while the other three indicate if the plan includes an iPhone, a Samsung, or another smartphone brand (Nokia, HTC, Blackberry, Sony, etc.), which are less frequent in our dataset and less popular among consumers worldwide.

The expected effect of including a smartphone in the plan is unclear. In fact, mobile operators provide smartphones to millions of consumers and some operators are present in several countries. This situation should allow them to negotiate price discounts that can be, if there is sufficient competition, passed through to consumers. Yet, smartphones are a differentiated

\footnotetext{
${ }^{3}$ According to the FCC (2015), advertising in relation to download speeds varies widely across countries. Operators in countries such as Hong Kong, Italy and Poland advertise the theoretical maximum available speeds (i.e., they report $100 \mathrm{Mbps}$ for 4G and 42.2 Mbps for 3G HSPA+). In contrast, the highest speed advertised for a 4G plan in the United States is $5-12$ Mbps and for a $3 G$ plan it is 7.2 Mbps.

${ }^{4}$ The dataset contains nine plans using $1 \mathrm{G}$ or $2 \mathrm{G}$ technologies and they are excluded from our analysis.
} 
product and some are clearly more sophisticated and expensive than others. Taking this into account, operators can use smartphones to identify consumers with a greater willingness to pay for the service and who they can charge a higher monthly tariff.

The price equation includes other variables that are related to the level of market competition. The variable Nplans is the number of plans released by MNOs in each year. The effect of the number of plans on the price is ambiguous. On the one hand, operators might release a large number of plans to price discriminate consumers or to generate confusion or misunderstanding (Hoernig, 2001). On the other hand, in competitive markets, operators may be forced to release more plans and set lower prices to fight competitors. As Baumol (2005) shows, in markets with no entry barriers if sellers can separate their consumers into distinct submarkets with different demand elasticities and arbitrage is not possible, price discrimination is necessary if losses are to be avoided. For instance, in the telecommunications market the entry of MVNOs might induce MNOs to release specific plans for low income/lighter consumers.

Finally, historical firms may use different commercial strategies to those adopted by entrants. To account for this possibility, we use the dummy variable Historical Operator, which takes a value of one for incumbent mobile operators. Operators that entered the market at the end of the nineties acquired a high presence and have been able to build a good reputation among consumers. We seek to determine if this "first mover advantage" has a persistent effect on prices.

\section{The data}

We examine mobile broadband prices by drawing on information from the "International Broadband Data Report" prepared by the FCC. ${ }^{5}$ The dataset contains 2,909 residential retail mobile broadband plans for smartphones collected from 37 countries around the globe, including all OECD countries. We focus on MNO plans for smartphones, although operators also commercialize broadband services for laptops and tablets connected via a USB modem or a MiFi (wireless router). The dataset does not include MVNO plans.

The FCC collects information about the prices and characteristics of the plans from the operators' websites, although operators might offer alternative plans via channels other than the Internet. All retail broadband prices are converted to US dollars using the Purchasing Power Parity (PPP) currency conversions published by the World Bank. Over the life of a contract, customers pay recurring costs (the monthly tariff) and non-recurring fees, such as activation costs paid at the beginning of the contract, promotions and rebates applied to the bill. The broadband prices used in our analysis do not include the cost of the smartphone device. Table 1 shows the basic statistics for the main components of the prices and the plans. Around $85 \%$ of the plans examined bundle several services, which usually include Internet, telephone calls and text messages. Most plans are volume metered: only 10\% of the plans offer unlimited volume

\footnotetext{
${ }^{5}$ Our dataset includes the third and fourth issues of the FCC report. See: http://www.fcc.gov/document/fourthinternational-broadband-data-report-2015. The original dataset contains information for 40 countries, but the FCC signals in the methodology of its "Fourth International Broadband Data Report” that data for Greece, Brazil, and Turkey are inconsistent from year to year. For this reason, we do not consider these countries.
} 
allowances and around $30 \%$ of bundled plans have unlimited minutes of telephone calls. The dataset does not include multi-play plans which combine fixed and mobile services.

Table 2 summarizes the characteristics of the plans offered in each country during the period 2013-2014. In these years, only operators in 8 countries offered unlimited data plans, while in the period 2011-2012 there were 17. In contrast, there has been an increase in the volume allowances. While in the period 2011-2012 the average volume allowance was around $2.5 \mathrm{~GB}$, in the period 2013-2014 this increased to 4 GB. Finland is the country with the highest number of unlimited plans (71\% of the total) and Sweden is the country offering the plan with the highest data allowance (80 GB). At the same time, the number of minutes of telephone calls in plans with limited voice caps has more than doubled on average since 2011, reaching around one thousand minutes per month in 2014. In spite of these changes, the average monthly price in our sample has stayed constant over the period 2011-2014 at around \$50 (\$PPP).

Table 1: Summary statistics of the FCC dataset of mobile broadband plans ( 37 countries)

\begin{tabular}{|c|c|c|c|c|c|}
\hline Variable & $\begin{array}{c}\text { Number of } \\
\text { plans }\end{array}$ & Average & $\begin{array}{l}\text { Standard } \\
\text { deviation }\end{array}$ & Minimum & Maximum \\
\hline Price (\$PPP)* & 2909 & 48.6 & 37.1 & 1.1 & 271.2 \\
\hline Monthly tariff (\$PPP) & 2909 & 50.0 & 37.4 & 1.1 & 271.2 \\
\hline Monthly promotion (\$PPP) & 2909 & 4.8 & 17.8 & 0.0 & 215.0 \\
\hline Activation costs (\$PPP) & 2909 & 6.6 & 16.3 & 0.0 & 225.1 \\
\hline Rebate (\$PPP) & 2909 & 8.7 & 51.1 & 0.0 & 449.0 \\
\hline Highest download speed (Mbps) & 2126 & 30.1 & 36.1 & 0.1 & 150.0 \\
\hline Volume allowance $(G B)^{\star \star}$ & 2579 & 3.5 & 6.4 & 0.0 & 80.0 \\
\hline Voice allowance (minutes)*** & 1448 & 663 & 1434 & 0 & 10000 \\
\hline Contract duration (months) & 2717 & 18.5 & 8.0 & 1 & 36 \\
\hline
\end{tabular}

* Price is defined as the average monthly price paid by a customer in a 24 months plan.

** There are 209 plans with unlimited data.

*** There are 794 bundles with unlimited minutes and 259 plans that do not include voice minute allowances.

The penalties faced by consumers when they exceed the contracted data allowance vary greatly across countries. Table 3 shows that in many countries, including Austria, Bulgaria, Denmark, Germany, Hungary, Poland, Spain and Sweden, operators frequently use speed reductions (the speed is usually reduced to 56/128 kbps). By contrast, in Australia, India, Lithuania, New Zealand, Norway and Slovenia, consumers are more typically switched to a pay-as-you-go system. In this case, operators usually charge per unit of volume (megabyte/kilobyte) and just some of them charge per unit of time (hour or day). In Iceland, the UK, Mexico, Singapore, Canada, the Netherlands and Japan consumers that exceed the contracted allowance are automatically changed to a new one (they contract a larger number of GB). Finally, only in a few countries, including Belgium and Korea, do operators actually curtail the service when consumers exceed the allowance.

Table 4 shows the percentage of plans in each country that include a smartphone, where the device might be an iPhone, a Samsung or another brand (Blackberry, Nokia, HTC, LG, Sony, etc.). In the data set there are several countries in which operators do not offer SIM-only plans. Notice, also, that most plans include an iPhone or a Samsung. 
The length of the contract is usually related to the type of smartphone included in the offer. Table 5 shows that contracts for SIM-only plans have a duration of 16.5 months on average, those for iPhone and Samsung of 19 months, and those for Other Brands of 18 months. The median duration of the contracts is even shorter for SIM-only plans compared to smartphone plans, i.e., 12 vs. 24 months.

Table 2: Mobile broadband Plans 2013/2014. Average values of characteristics by country

\begin{tabular}{|c|c|c|c|c|c|c|c|c|c|c|c|c|}
\hline & $\begin{array}{l}\text { Number } \\
\text { of plans }\end{array}$ & $\begin{array}{c}\text { Number of } \\
\text { mobile } \\
\text { operators }\end{array}$ & $\begin{array}{c}\text { Price } \\
\text { (\$PPP)* }\end{array}$ & $\begin{array}{l}\text { Monthly } \\
\text { tariff } \\
\text { (\$PPP) }\end{array}$ & $\begin{array}{c}\text { Maximum } \\
\text { download } \\
\text { speed } \\
\text { (Mbps) }\end{array}$ & $\begin{array}{c}\text { Ratio 4G } \\
\text { plans } \\
\text { over 3G } \\
(\%)\end{array}$ & $\begin{array}{l}\text { Unlimited } \\
\text { data } \\
\text { plans (\%) }\end{array}$ & $\begin{array}{c}\text { Volume } \\
\text { cap (GB) }\end{array}$ & $\begin{array}{c}\text { Bundled } \\
\text { plans with } \\
\text { minutes } \\
\text { of voice } \\
(\%)\end{array}$ & $\begin{array}{c}\text { Bundles } \\
\text { with } \\
\text { unlimited } \\
\text { minutes (\%) }\end{array}$ & $\begin{array}{l}\text { Voice cap } \\
\text { (minutes) }\end{array}$ & $\begin{array}{l}\text { Contract } \\
\text { duration } \\
\text { (months) }\end{array}$ \\
\hline Australia & 20 & 2 & 44.3 & 44.3 & 15.4 & 50 & 0 & 2.5 & 100 & 40 & 427 & 18 \\
\hline Austria & 18 & 3 & 42.2 & 41.2 & 26.6 & 100 & 6 & 3.2 & 100 & 56 & 1300 & 24 \\
\hline Belgium & 30 & 4 & 42.9 & 43.8 & 38.0 & 100 & 0 & 2.4 & 100 & 30 & 198 & 9 \\
\hline Bulgaria & 19 & 3 & 42.4 & 42.4 & 42.0 & 0 & 0 & 1.3 & 100 & 0 & 1601 & 21 \\
\hline Canada & 74 & 3 & 34.0 & 35.3 & 131.8 & 100 & 0 & 5.1 & 100 & 100 & - & 13 \\
\hline Chile & 20 & 3 & 129.3 & 129.3 & 9.2 & 50 & 0 & 4.4 & 100 & 0 & 666 & 14 \\
\hline Czech Republic & 69 & 3 & 52.2 & 52.2 & 74.9 & 100 & 0 & 2.9 & 100 & 100 & - & 18 \\
\hline Denmark & 37 & 3 & 21.8 & 21.7 & 66.9 & 92 & 0 & 4.8 & 100 & 58 & 204 & 15 \\
\hline Estonia & 9 & 2 & 26.8 & 26.8 & 35.3 & 33 & 0 & 8.4 & 100 & 13 & 411 & 24 \\
\hline Finland & 7 & 3 & 16.3 & 16.3 & 37.4 & 43 & 71 & 0.2 & 43 & 0 & 43 & 19 \\
\hline France & 62 & 4 & 49.2 & 49.8 & 87.1 & 94 & 0 & 4.0 & 100 & 74 & 120 & 20 \\
\hline Germany & 44 & 3 & 61.3 & 61.0 & 45.2 & 91 & 0 & 4.8 & 100 & 73 & 125 & 24 \\
\hline Hong Kong & 34 & 5 & 49.7 & 49.7 & 31.2 & 53 & 22 & 3.1 & 100 & 10 & 2008 & 19 \\
\hline Hungary & 14 & 2 & 62.4 & 62.4 & 76.2 & 64 & 0 & 1.1 & 86 & 36 & 190 & 22 \\
\hline Iceland & 17 & 2 & 32.4 & 32.4 & 14.9 & 47 & 0 & 3.0 & 100 & 40 & 122 & 12 \\
\hline India & 51 & 4 & 39.1 & 40.8 & 21.5 & 12 & 0 & 3.9 & 100 & 0 & 6966 & 12 \\
\hline Ireland & 39 & 3 & 54.4 & 54.4 & 21.0 & 26 & 0 & 4.1 & 100 & 31 & 298 & 18 \\
\hline Israel & 5 & 2 & 21.1 & 21.1 & 4.0 & 0 & 0 & 3.0 & 100 & 80 & 300 & 12 \\
\hline Italy & 28 & 4 & 41.3 & 44.5 & 52.5 & 32 & 4 & 2.3 & 100 & 50 & 348 & 25 \\
\hline Japan & 17 & 3 & 32.2 & 32.2 & 75.0 & 92 & 38 & 4.4 & - & - & - & 24 \\
\hline Korea (South) & 16 & 3 & 47.5 & 47.5 & - & 100 & 0 & 2.2 & 100 & 0 & 110 & 12 \\
\hline Lithuania & 23 & 3 & 9.1 & 8.9 & 18.0 & 0 & 0 & 1.3 & 100 & 8 & 730 & 8 \\
\hline Luxembourg & 9 & 3 & 8.0 & 17.8 & 29.5 & 67 & 0 & 12.4 & 100 & 0 & 87 & 13 \\
\hline Mexico & 29 & 2 & 69.9 & 69.9 & 18.4 & 100 & 0 & 1.7 & 100 & 0 & 567 & 17 \\
\hline New Zealand & 19 & 1 & 53.5 & 53.5 & 7.2 & 26 & 0 & 1.4 & 100 & 32 & 337 & 20 \\
\hline Norway & 13 & 1 & 35.2 & 35.2 & 19.4 & 100 & 0 & 2.2 & 100 & 100 & - & 12 \\
\hline Poland & 39 & 3 & 36.3 & 36.3 & - & 13 & 0 & 1.3 & 100 & 42 & 400 & 24 \\
\hline Portugal & 17 & 3 & 54.2 & 54.5 & 39.0 & 71 & 18 & 1.3 & 82 & 29 & 909 & 17 \\
\hline Singapore & 20 & 3 & 87.6 & 87.5 & 86.6 & 100 & 0 & 5.4 & 100 & 20 & 378 & 24 \\
\hline Slovakia & 6 & 3 & 48.4 & 48.4 & 33.8 & 33 & 0 & 1.6 & 100 & 67 & 125 & 22 \\
\hline Slovenia & 37 & 4 & 10.3 & 20.1 & 42.0 & 14 & 0 & 1.9 & 100 & 0 & 598 & 21 \\
\hline Spain & 29 & 5 & 40.0 & 43.7 & 9.0 & 59 & 0 & 1.4 & 89 & 33 & 172 & 24 \\
\hline Sweden & 39 & 3 & 42.1 & 42.0 & 42.6 & 54 & 0 & 8.7 & 29 & 0 & 626 & 11 \\
\hline Switzerland & 11 & 3 & 22.7 & 27.4 & 100.0 & 100 & 0 & 4.1 & 38 & 0 & 23 & 24 \\
\hline The Netherlands & 32 & 4 & 54.6 & 64.8 & 30.4 & 81 & 0 & 1.9 & 97 & 28 & 189 & 22 \\
\hline United Kingdom & 22 & 5 & 52.2 & 52.8 & - & 36 & 18 & 3.5 & 100 & 68 & 1014 & 21 \\
\hline United States & 161 & 7 & 84.1 & 85.8 & 17.4 & 99 & 4 & 8.2 & 100 & 100 & - & 13 \\
\hline
\end{tabular}


Table 3: Internet usage penalties by country

\begin{tabular}{|c|c|c|c|c|c|c|}
\hline & $\begin{array}{l}\text { Number } \\
\text { of plans }\end{array}$ & $\begin{array}{c}\text { No } \\
\text { penalization } \\
\text { (\% unlimited } \\
\text { plans) }\end{array}$ & $\begin{array}{c}\text { Speed } \\
\text { reduction } \\
(\%)\end{array}$ & $\begin{array}{c}\text { Jump to } \\
\text { pay as you } \\
\text { go (\%) }\end{array}$ & $\begin{array}{c}\text { Jump to } \\
\text { new } \\
\text { allowance } \\
\text { (\%) }\end{array}$ & $\begin{array}{c}\text { End of } \\
\text { service (\%) }\end{array}$ \\
\hline Australia & 82 & 0 & 0 & 91 & 9 & 0 \\
\hline Austria & 40 & 3 & 85 & 0 & 10 & 3 \\
\hline Belgium & 49 & 2 & 24 & 49 & 0 & 24 \\
\hline Bulgaria & 62 & 0 & 100 & 0 & 0 & 0 \\
\hline Canada & 93 & 0 & 0 & 47 & 53 & 0 \\
\hline Chile & 37 & 3 & 59 & 30 & 8 & 0 \\
\hline Czech Republic & 26 & 0 & 65 & 0 & 35 & 0 \\
\hline Denmark & 54 & 0 & 89 & 4 & 7 & 0 \\
\hline Estonia & 21 & 29 & 71 & 0 & 0 & 0 \\
\hline Finland & 21 & 52 & 48 & 0 & 0 & 0 \\
\hline France & 136 & 0 & 76 & 3 & 21 & 0 \\
\hline Germany & 68 & 10 & 88 & 1 & 0 & 0 \\
\hline Hong Kong & 80 & 39 & 15 & 34 & 13 & 0 \\
\hline Hungary & 57 & 2 & 93 & 0 & 5 & 0 \\
\hline Iceland & 29 & 0 & 0 & 14 & 86 & 0 \\
\hline India & 76 & 0 & 24 & 68 & 8 & 0 \\
\hline Ireland & 103 & 15 & 6 & 50 & 29 & 0 \\
\hline Israel & 1 & 0 & 0 & 0 & 0 & 100 \\
\hline Italy & 57 & 16 & 35 & 11 & 39 & 0 \\
\hline Japan & 56 & 29 & 14 & 11 & 46 & 0 \\
\hline Korea (South) & 141 & 17 & 0 & 60 & 0 & 23 \\
\hline Lithuania & 59 & 5 & 0 & 86 & 8 & 0 \\
\hline Luxembourg & 39 & 5 & 10 & 67 & 18 & 0 \\
\hline Mexico & 64 & 0 & 6 & 20 & 70 & 3 \\
\hline New Zealand & 62 & 0 & 0 & 97 & 3 & 0 \\
\hline Norway & 33 & 0 & 30 & 70 & 0 & 0 \\
\hline Poland & 55 & 5 & 84 & 7 & 4 & 0 \\
\hline Portugal & 33 & 18 & 6 & 52 & 24 & 0 \\
\hline Singapore & 38 & 0 & 24 & 16 & 61 & 0 \\
\hline Slovakia & 24 & 29 & 63 & 8 & 0 & 0 \\
\hline Slovenia & 65 & 0 & 14 & 71 & 15 & 0 \\
\hline Spain & 84 & 2 & 98 & 0 & 0 & 0 \\
\hline Sweden & 65 & 9 & 86 & 0 & 5 & 0 \\
\hline Switzerland & 54 & 37 & 41 & 20 & 2 & 0 \\
\hline The Netherlands & 85 & 0 & 24 & 27 & 49 & 0 \\
\hline United Kingdom & 84 & 15 & 5 & 0 & 80 & 0 \\
\hline United States & 273 & 9 & 29 & 17 & 42 & 4 \\
\hline Total & 2,406 & 9 & 36 & 30 & 23 & 2 \\
\hline
\end{tabular}


Table 4: Summary of SIM-only and plans with a smartphone by country

\begin{tabular}{|c|c|c|c|c|c|c|}
\hline & $\begin{array}{c}\text { Number of } \\
\text { plans }\end{array}$ & $\begin{array}{c}\text { SIM only plans } \\
\text { (\%) }\end{array}$ & $\begin{array}{l}\text { Plan includes } \\
\text { an iPhone (\%) }\end{array}$ & $\begin{array}{l}\text { Plan includes } \\
\text { a Samsung } \\
\text { (\%) }\end{array}$ & $\begin{array}{c}\text { Plan includes } \\
\text { Other brands } \\
\text { (\%) }\end{array}$ & $\begin{array}{l}\text { Average } \\
\text { contract } \\
\text { duration }\end{array}$ \\
\hline Australia & 80 & 26 & 68 & 0 & 6 & 19 \\
\hline Austria & 40 & 28 & 60 & 0 & 13 & 24 \\
\hline Belgium & 44 & 39 & 30 & 18 & 14 & 12 \\
\hline Bulgaria & 42 & 12 & 21 & 67 & 0 & 18 \\
\hline Canada & 93 & 8 & 52 & 33 & 8 & 18 \\
\hline Chile & 40 & 3 & 85 & 13 & 0 & 17 \\
\hline Czech Republic & 93 & 0 & 23 & 70 & 8 & 19 \\
\hline Denmark & 58 & 0 & 86 & 0 & 14 & 17 \\
\hline Estonia & 24 & 17 & 0 & 75 & 8 & 24 \\
\hline Finland & 21 & 0 & 76 & 0 & 24 & 21 \\
\hline France & 186 & 9 & 31 & 16 & 45 & 19 \\
\hline Germany & 76 & 0 & 47 & 32 & 21 & 23 \\
\hline Hong Kong & 77 & 22 & 32 & 21 & 25 & 19 \\
\hline Hungary & 60 & 2 & 32 & 32 & 35 & 24 \\
\hline Iceland & 34 & 0 & 65 & 35 & 0 & 11 \\
\hline India & 75 & 9 & 11 & 11 & 69 & 10 \\
\hline Ireland & 139 & 4 & 27 & 19 & 50 & 14 \\
\hline Israel & 16 & 0 & 38 & 25 & 38 & 13 \\
\hline Italy & 71 & 10 & 39 & 34 & 17 & 22 \\
\hline Japan & 32 & 0 & 78 & 22 & 0 & 24 \\
\hline Korea (South) & 97 & 45 & 14 & 32 & 8 & 23 \\
\hline Lithuania & 52 & 2 & 52 & 25 & 21 & 23 \\
\hline Luxembourg & 30 & 17 & 30 & 10 & 43 & 19 \\
\hline Mexico & 60 & 0 & 67 & 12 & 22 & 19 \\
\hline New Zealand & 62 & 5 & 58 & 11 & 26 & 18 \\
\hline Norway & 33 & 0 & 73 & 0 & 27 & 12 \\
\hline Poland & 71 & 0 & 13 & 44 & 44 & 21 \\
\hline Portugal & 40 & 0 & 75 & 0 & 25 & 16 \\
\hline Singapore & 32 & 13 & 28 & 47 & 13 & 24 \\
\hline Slovakia & 24 & 17 & 25 & 21 & 38 & 19 \\
\hline Slovenia & 97 & 13 & 10 & 64 & 12 & 22 \\
\hline Spain & 89 & 11 & 46 & 11 & 31 & 22 \\
\hline Sweden & 89 & 3 & 79 & 7 & 11 & 18 \\
\hline Switzerland & 62 & 19 & 63 & 5 & 13 & 15 \\
\hline The Netherlands & 111 & 14 & 24 & 50 & 12 & 20 \\
\hline United Kingdom & 105 & 5 & 35 & 21 & 39 & 23 \\
\hline United States & 275 & 0 & 40 & 46 & 14 & 14 \\
\hline Total & 2,630 & 9 & 41 & 27 & 23 & 19 \\
\hline
\end{tabular}

Table 5: Summary of contract duration (months) for SIM only plans and by smartphone brand

\begin{tabular}{lccccc}
\hline & $\begin{array}{l}\text { Number of } \\
\text { plans }\end{array}$ & $\begin{array}{c}\text { Average } \\
\text { contract } \\
\text { (months) }\end{array}$ & $\begin{array}{c}\text { Median } \\
\text { contract } \\
\text { (months) }\end{array}$ & $\begin{array}{c}\text { Minimum } \\
\text { contract } \\
\text { (months) }\end{array}$ & $\begin{array}{c}\text { Maximun } \\
\text { contract } \\
\text { (months) }\end{array}$ \\
\hline SIM only & 238 & 16.5 & 12 & 1 & 36 \\
iPhone & 1,029 & 19.1 & 24 & 1 & 36 \\
Samsung & 705 & 19.4 & 24 & 1 & 36 \\
Other brands & 590 & 18.0 & 24 & 1 & 36 \\
\hline Total & 2,562 & 18.7 & 24 & 1 & 36 \\
\hline
\end{tabular}




\section{Estimation and Results}

This section presents the estimates of the pricing model in (1) when considering the whole sample of countries. Table 6 presents the OLS results for different specifications of this model: specifications 1-5 consider all the sample and specifications 6 and 7 only examine 12- and 24month plans, respectively. Most of the results obtained are in line with the hypotheses that we have formulated in the previous section and they are robust to different specifications of the model. The coefficient of the dummy variable Limited Data (presence of volume allowances) is always negative and significant, which implies that usage-based plans are substantially cheaper than unlimited plans. As explained, volume caps may be used as a second price discrimination mechanism to extract consumer surplus and to avoid congestion.

In specifications 5 to 7 we have disaggregated the variable Limited Data in four dummies that reflect the penalties imposed in usage-based plans. In specifications 5 and 7, the four dummies have negative and significant coefficients, re-affirming that usage-based plans are cheaper than unlimited plans. By contrast, in specification 6 (12-month plans) the penalties Jump to Pay-asyou-go and Jump to New Allowance are not significant. Recall that the users of these plans incur additional fees when they exceed the volume allowance. Finally, notice that in all specifications the plans that imply the termination of the service when the cap is exceeded are the cheapest.

The coefficients of the Volume and Volume ${ }^{2}$ variables are significant in all specifications and present the expected sign. The results for Volume imply that an additional gigabyte in the cap of usage-based plans has a positive impact of more than $9 \%$ on the monthly price paid by the customer, and the negative coefficient of $V_{\text {olume }}^{2}$ indicates that operators apply volume discounts. On the other hand, notice that volume allowance coefficients are larger in the 12month plans than those in the 24-month plans. Operators therefore are willing to reduce the monthly price if customers enter into longer contracts, which are usually associated with the purchase of a smartphone.

As for Technology, only $4 G$ is significant in specifications 1 and 3, but the variable loses its significance when we include Download Speed in specifications 4-7. Our intuition for this is that although some operators might have set a premium for the 4G service after its launch, the pressure of competition soon forced them to offer the service to all consumers at the previous price. For instance, in Spain, Vodafone initially charged a higher price for 4G, but it quickly eliminated the premium price when other firms started offering the same product. In the UK, Three decided to offer $4 \mathrm{G}$ plans at the same price as $3 \mathrm{G}$ plans and this put competitive pressure on its rivals. In contrast, the coefficient for Speed is positive and significant in specifications 4 and 5, showing that prices increase with the quality of the service. The results imply that a 10 Mbps increase in speed raises the price of the plan by around $2 \% .{ }^{6}$ Notice that the inclusion of Speed in the regressions notably reduces the number of observations, since quite often operators do not mention the speed of the plans in their websites. For this reason, we do not include this variable in specifications 6 and 7. All in all, these results suggest that operators are better able to

\footnotetext{
${ }^{6}$ For the dummy variables we follow the interpretation of Halvorsen and Palmquist (1980) whereby, in semi-logarithmic regression models, coefficients are interpreted as $100 *$ [exponential (coefficient)-1] with respect to the reference.
} 
charge a premium price by advertising high speeds than by advertising the use of a new technology such as $4 \mathrm{G}$.

Specifications 3 to 7 include two variables that reflect the effects of bundling broadband and voice services. The Limited Voice Minutes variable is negative and significant in all specifications, showing that plans that offer a limited number of telephone calls are cheaper than those that offer unlimited calls. On the other hand, the coefficient of the variable Minutes of Voice, expressed as hundreds of minutes, is positive but only significant in specification 7 (24month plans). Hence, the number of voice minutes in the plan only is associated to the bundle price in long contracts.

\begin{tabular}{|c|c|c|c|c|c|c|c|}
\hline Dependent variable & Specification 1 & Specification 2 & Specification 3 & Specification 4 & Specification 5 & Specification 6 & Specification 7 \\
\hline Log Price (price) & OLS & OLS & OLS & OLS & OLS & OLS & OLS \\
\hline Independent variables & Coefficient & Coefficient & Coefficient & Coefficient & Coefficient & Coefficient & Coefficient \\
\hline Download Speed & & $\begin{array}{l}\mathbf{0 . 0 0 2} \\
(0.001)\end{array}$ & & 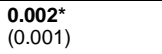 & $\begin{array}{l}\mathbf{0 . 0 0 2} \text { ** } \\
(0.001)\end{array}$ & & \\
\hline \multicolumn{8}{|l|}{ Technology (reference: 3G) } \\
\hline $3.5 \mathrm{G} / 3.75 \mathrm{G}$ & $\begin{array}{l}-0.076 \\
(0.215)\end{array}$ & & $\begin{array}{l}\mathbf{0 . 1 2 3} \\
(0.272)\end{array}$ & $\begin{array}{l}-0.001 \\
(0.236)\end{array}$ & $\begin{array}{l}-0.135 \\
(0.194)\end{array}$ & $\begin{array}{l}-0.284 \\
(0.365)\end{array}$ & $\begin{array}{l}-0.131 \\
(0.282)\end{array}$ \\
\hline $4 \mathrm{G}$ & $\begin{array}{l}\mathbf{0 . 2 4 2 * * \star} \\
(0.088)\end{array}$ & & $\begin{array}{l}\mathbf{0 . 2 1 3 ^ { * }} \\
(0.107)\end{array}$ & $\begin{array}{l}\mathbf{0 . 0 4 1} \\
(0.087)\end{array}$ & $\begin{array}{l}\mathbf{0 . 0 7 9} \\
(0.101)\end{array}$ & $\begin{array}{l}0.100 \\
(0.241)\end{array}$ & $\begin{array}{l}-0.005 \\
(0.081)\end{array}$ \\
\hline Volume & 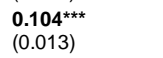 & $\begin{array}{l}\mathbf{0 . 0 9 1} \text { *ᄎ* } \\
(0.014)\end{array}$ & $\begin{array}{l}\mathbf{0 . 0 9 3} \text { ***} \\
(0.014)\end{array}$ & $\begin{array}{l}\mathbf{0 . 0 9 0 * \star \star} \\
(0.014)\end{array}$ & $\begin{array}{l}\mathbf{0 . 0 9 2} \text { «** } \\
(0.012)\end{array}$ & $\begin{array}{l}\mathbf{0 . 1 7 6 * \star \star} \\
(0.044)\end{array}$ & $\begin{array}{l}\mathbf{0 . 0 8 9 * * *} \\
(0.01)\end{array}$ \\
\hline Volume $^{2}$ & $\begin{array}{l}-0.002^{\star \star *} \\
(0.0004)\end{array}$ & $\begin{array}{l}-0.001^{\star * *} \\
(0.0003)\end{array}$ & $\begin{array}{l}-0.001^{\star * *} \\
(0.0004)\end{array}$ & $\begin{array}{l}-0.001^{\star \star *} \\
(0.0003)\end{array}$ & $\begin{array}{l}-0.001 \text { * } \\
(0.0002)\end{array}$ & $\begin{array}{l}-0.005^{\star \star *} \\
(0.0002)\end{array}$ & $\begin{array}{l}-0.001 \text { * } \\
(0.0002)\end{array}$ \\
\hline Limited Data & $\begin{array}{l}-0.431^{\star \star *} \\
(0.135)\end{array}$ & $\begin{array}{l}-0.515^{\star \star *} \\
(0.095)\end{array}$ & $\begin{array}{l}-0.343^{\star *} \\
(0.14)\end{array}$ & $\begin{array}{l}-0.453^{\text {** }} \\
(0.14)\end{array}$ & & & \\
\hline \multicolumn{8}{|c|}{ Penalty (reference: Unlimited data) } \\
\hline Speed reduction & & & & & $\begin{array}{l}-0.482^{\star \star *} \\
(0.142)\end{array}$ & $\begin{array}{l}-0.673^{*} \\
(0.326)\end{array}$ & $\begin{array}{l}-0.380^{*} \\
(0.203)\end{array}$ \\
\hline Jump to pay as you go & & & & & $\begin{array}{l}-0.545^{\star \star \star} \\
(0.179)\end{array}$ & $\begin{array}{l}-0.531 \\
(0.335)\end{array}$ & $\begin{array}{l}-0.452^{* *} \\
(0.176)\end{array}$ \\
\hline Jump to new allowance & & & & & $\begin{array}{l}-0.423^{* *} \\
(0.159)\end{array}$ & $\begin{array}{l}0.143 \\
(0.27)\end{array}$ & $\begin{array}{l}-0.483^{* *} \\
(0.182)\end{array}$ \\
\hline End of service & & & & & $\begin{array}{l}-0.732^{\star \star *} \\
(0.158)\end{array}$ & $\begin{array}{l}-0.833^{\star \star *} \\
(0.212)\end{array}$ & $\begin{array}{l}-0.637^{\star \star *} \\
(0.182)\end{array}$ \\
\hline Limited Voice Minutes & & & $\begin{array}{l}-0.435^{\star \star *} \\
(0.109)\end{array}$ & $\begin{array}{l}-0.467^{\star \star *} \\
(0.099)\end{array}$ & $\begin{array}{l}-0.463^{* * *} \\
(0.105)\end{array}$ & $\begin{array}{l}-0.445^{\star \star} \\
(0.203)\end{array}$ & $\begin{array}{l}-0.501 \text { (** } \\
(0.096)\end{array}$ \\
\hline Minutes of Voice & & & $\begin{array}{l}\mathbf{0 . 0 1 0} \\
(0.007)\end{array}$ & $\begin{array}{l}\mathbf{0 . 0 0 9} \\
(0.007)\end{array}$ & $\begin{array}{l}0.009 \\
(0.007)\end{array}$ & $\begin{array}{l}0.001 \\
(0.006)\end{array}$ & $\begin{array}{l}\mathbf{0 . 0 2 4} 4^{\star \star \star} \\
(0.006)\end{array}$ \\
\hline \multicolumn{8}{|l|}{ Smartphone (reference: SIM only) } \\
\hline iPhone & & & & $\begin{array}{l}\mathbf{0 . 3 2 3} \text { ** } \\
(0.128)\end{array}$ & $\begin{array}{l}\mathbf{0 . 3 6 9 * *} \\
(0.158)\end{array}$ & $\begin{array}{l}\mathbf{0 . 1 6 9} \\
(0.222)\end{array}$ & $\begin{array}{l}\mathbf{0 . 3 5 9 * *} \\
(0.143)\end{array}$ \\
\hline Samsung & & & & $\begin{array}{l}\mathbf{0 . 2 2 4} \\
(0.136)\end{array}$ & $\begin{array}{l}\text { 0.307* } \\
(0.168)\end{array}$ & $\begin{array}{l}\mathbf{0 . 6 1 1} \\
(0.366)\end{array}$ & $\begin{array}{l}\mathbf{0 . 2 5 2} \\
(0.166)\end{array}$ \\
\hline Other brands & & & & $\begin{array}{l}\mathbf{0 . 0 6 2} \\
(0.148)\end{array}$ & $\begin{array}{l}\mathbf{0 . 1 0 9} \\
(0.186)\end{array}$ & $\begin{array}{l}0.321 \\
(0.19)\end{array}$ & $\begin{array}{l}\mathbf{0 . 0 8 1} \\
(0.205)\end{array}$ \\
\hline Historic Operator & & & & & $\begin{array}{l}\mathbf{0 . 0 9 4} \\
(0.095)\end{array}$ & $\begin{array}{l}-0.255 \\
(0.277)\end{array}$ & $\begin{array}{l}\mathbf{0 . 1 0 7} \\
(0.088)\end{array}$ \\
\hline Nplans & & & & & $\begin{array}{l}-0.001 \\
(0.002)\end{array}$ & $\begin{array}{l}\mathbf{0 . 0 0 1} \\
(0.02)\end{array}$ & $\begin{array}{l}\mathbf{0 . 0 0 1 0} \\
(0.003)\end{array}$ \\
\hline \multicolumn{8}{|c|}{ Time Dummy (reference: year 2011) } \\
\hline year 2012 & $\begin{array}{l}-0.053 \\
(0.112)\end{array}$ & $\begin{array}{l}\mathbf{0 . 0 6 2} \\
(0.086)\end{array}$ & $\begin{array}{l}\mathbf{0 . 0 8 2} \\
(0.146)\end{array}$ & $\begin{array}{l}-0.058 \\
(0.111)\end{array}$ & $\begin{array}{l}\mathbf{0 . 0 5 4} \\
(0.098)\end{array}$ & $\begin{array}{l}\mathbf{0 . 0 6 0} \\
(0.162)\end{array}$ & $\begin{array}{l}-0.340^{*} \\
(0.195)\end{array}$ \\
\hline year 2013 & $\begin{array}{l}-0.106 \\
(0.105)\end{array}$ & $\begin{array}{l}0.032 \\
(0.099)\end{array}$ & $\begin{array}{l}0.007 \\
(0.144)\end{array}$ & $\begin{array}{l}-0.121 \\
(0.125)\end{array}$ & $\begin{array}{l}-0.14 \\
(0.096)\end{array}$ & $\begin{array}{l}-0.212 \\
(0.147)\end{array}$ & $\begin{array}{l}-0.395^{*} \\
(0.203)\end{array}$ \\
\hline year 2014 & $\begin{array}{l}-0.376^{*} \\
(0.211)\end{array}$ & $\begin{array}{l}-0.062 \\
(0.134)\end{array}$ & $\begin{array}{l}-0.446^{*} \\
(0.235)\end{array}$ & $\begin{array}{l}-0.407^{* * *} \\
(0.142)\end{array}$ & $\begin{array}{l}-0.318^{* *} \\
(0.122)\end{array}$ & $\begin{array}{l}-0.147 \\
(0.197)\end{array}$ & $\begin{array}{l}-0.481^{* *} \\
(0.179)\end{array}$ \\
\hline Constant & $\begin{array}{l}\text { 3.826*** } \\
(0.129)\end{array}$ & $\begin{array}{l}3.966^{\star \star \star \star} \\
(0.092)\end{array}$ & $\begin{array}{l}3.958^{\star \star \star *} \\
(0.205)\end{array}$ & $\begin{array}{l}4.031^{\star \star \star} \\
(0.149)\end{array}$ & $\begin{array}{l}4.021 \text { *** } \\
(0.212)\end{array}$ & $\begin{array}{l}3.898^{* \star *} \\
(0.522)\end{array}$ & $\begin{array}{l}4.483^{\star \star *} \\
(0.188)\end{array}$ \\
\hline$R^{2}$ & 0.44 & 0.39 & 0.51 & 0.48 & 0.52 & 0.58 & 0.56 \\
\hline Number of observations $(N)$ & 2696 & 2027 & 2164 & 1607 & 1391 & 288 & 1154 \\
\hline
\end{tabular}

We also analyze how the inclusion of a smartphone in the plan affects the price of the broadband service, although we do not have information regarding smartphone prices to determine the 
overall charge made to consumers. In specifications 4 to 7, the Smartphone variable takes as its reference the SIM-only plans and shows that plans including an iPhone might be over $30 \%$ more expensive. The dummy for Samsung is only weakly significant in specification 5 , when we consider all the plans and the penalties. Our intuition regarding this result is that operators set higher prices for plans that include an iPhone because this choice denotes a greater willingness to pay on the part of the consumer (third degree price discrimination), or because the consumers that choose this brand make a larger use of the bandwidth. ${ }^{7}$

A further question of interest is to determine how operators use smartphone price discounts to attract consumers. Our data set contains few observations with information about this commercial practice $(\mathrm{N}=639)$, but to shed some light on this matter we have repeated the previous estimations when including the variable Discount in the price equation. Results show that discounts in smartphones prices have a positive and significant effect on the broadband price, suggesting that operators subsidize these discounts with the price of the mobile service to attract consumers. The results for this analysis are presented in Annex 2 in the Appendix. The first two specifications in the table use all the plans and the last two focus solely on 24-month plans.

The Historic Operator variable is not significant in specifications 5 to 7 . This implies that historical operators do not have a first-mover advantage with respect to the other MNOs and, therefore, there is no measurable rent to be gained from incumbency. Interestingly, this result contrasts with the situation in the fixed broadband market, where incumbent operators have been able to set higher prices than their competitors (Calzada and Martínez-Santos, 2014). Various factors might account for this situation. First, in many countries 3G and 4G licenses have been tendered simultaneously to several operators and so incumbents have initiated their commercialization of broadband services at the same time as their competitors. Second, the provision of $3 \mathrm{G}$ and $4 \mathrm{G}$ services has necessitated the installation of brand new infrastructure, thus reducing the cost advantages of existing operators. And third, in some countries, incumbents do not necessarily provide superior service quality than that provided by entrants and, therefore, they are unable to leverage rents from incumbency. For example, there is evidence from Spain that historical operators provide less consumer satisfaction than entrants, which might explain the evolution of their respective market shares in recent years (Gijon et al., 2013 and GarinMuñoz et al., 2015).

Finally, the estimations in Table 6 also show that the Nplans variable does not have a significant effect on prices. Therefore, we cannot conclude that the release of a large number of plans is a strategy for screening consumers and setting higher prices.

\footnotetext{
7 Sinkinson (2014) analyzes the exclusive contract that AT\&T signed with iPhone in the US between 2007 and 2011. Lyons (2013) reports that, after this agreement, the average iPhone user consumed ten times more bandwidth than a typical smartphone user. This could have motivated the introduction of three-part tariffs by AT\&T.
} 


\section{Effects of competition and regulation on prices}

This section introduces a new group of variables in the pricing model with the objective of analyzing how operators adjust their tariffs to the regulation and the intensity of competition. The FCC data set does not include information about the characteristics of national markets and for this reason we estimate the model by considering a sub-sample of 20 European countries for which we have obtained additional information from other sources. Table 7 describes the new variables introduced in this section for year 2014.

The new model includes the Herfindahl-Hirschman Index (HHI), a measure of market concentration, which is defined as the sum of the squares of the market shares of the operators in each country. We have obtained information about the operators' market shares (i.e., number of subscribers) from the websites of the European regulators. We expect markets with a high concentration to present higher prices. In spite of this, notice that the estimation of the price equation in (1) might be affected by the potential endogeneity of the $H H I$ variable, since the operators' market shares are affected by prices. Moreover, there are countervailing influences of the $H H I$ on prices, since large scale production can result in cost savings that reduce prices. The presence of unobserved efficiencies should be mitigated by the inclusion of country fixed effects. On the other hand, to account for the potential endogeneity of $H H I$, we estimate the model using 2SLS-IV and as instruments for $H H I$ we use variables that only affect prices indirectly via their impact on market concentration. Our candidates for these instruments are the Number of MNOS and Density of Population. Our hypothesis is that the number of MNOs affects the intensity of competition, but that it should not be related to market conditions since the number of licenses is determined by regulators taking into account technological restrictions. We also use Density of Population on the assumption that more densely populated regions enjoy better 3G and 4G coverage which should favor competition, and that this variable does not directly affect the prices set nationally.

We have verified that the instruments selected allow us to overcome the endogeneity problem. Specifically, they pass Hansen's J test for overidentifying restrictions. Moreover, we have considered the instrument suitability test (first-stage F-statistics of the $H H I$ variable over the instruments selected) to measure the strength of our instruments. We have also considered the use of other instruments, including the number of operators with LTE technology and the difference in the mobile termination charges of the least and most regulated operators in each country (Genakos et al., 2015), but we have concluded that the instruments that best fulfill the orthogonality condition and that best explain the $H H I$ variable are those described above.

As an alternative measure of competition intensity we use the MVNOs variable in some specifications of the model. We treat this variable as exogenous, on the grounds that in the European Union MVNOs are regulated by the National Regulatory Authorities (NRAs) and their profitability depends on the agreements reached with MNOs for the use of the spectrum. The number of MVNOs is expected to negatively impact broadband prices, since these operators usually adopt aggressive commercial policies to attract low income/light volume consumers. Despite this, MVNOs employ different commercial strategies, which can have different effects on the market. For example, while some have entered niche markets, others are low-cost subsidiaries of MNOs. Yet, in many countries MVNOs have yet to reach an agreement with 
MNOs for the provision of $4 \mathrm{G}$ and this can affect their market impact. Information for MVNOs has been obtained from the European Commission Directorate General for Communications Networks, Content \& Technology (DG-CONNECT).

Finally, the price equation also includes the $M T R$ variable, which represents the regulated mobile termination rates (\$PPP) set by the NRAs in each EU country. The termination rates are the prices that mobile operators charge for terminating the telephone calls of their rivals in their own network. ${ }^{8}$ These rates do not directly affect the cost of the broadband service but they do affect the cost of plans that include minute allowances. Termination rates increase the costs of off-net calls and should have a greater impact on operators that have a larger proportion of outgoing calls. In spite of this, the impact of these fees might have decreased in recent years. In 2009, the European authorities recommended that NRAs implement a "glide-path" so as to gradually reduce termination fees and eliminate rate asymmetries between operators. ${ }^{9}$ This policy has favored the convergence in on-net and off-net call prices and might, at the same time, have favored the change from usage-based prices to non-linear prices. Information on MTR has been obtained from DG-CONNECT.

Table 7: Competition and Regulation Indicators EU-20, year 2014

\begin{tabular}{lcccc}
\hline & $\begin{array}{c}\text { HHI } \\
\text { Operator }\end{array}$ & MNOs & MVNOs & MTR (\$PPP) \\
\hline Austria & 34.5 & 3 & 7 & 0.80 \\
Belgium & 29.6 & 3 & 2 & 1.18 \\
Czech Republic & 32.7 & 4 & 3 & 1.01 \\
Denmark & 25.1 & 5 & 2 & 0.90 \\
Estonia & 26.5 & 3 & 1 & 1.29 \\
Finland & 34.0 & 4 & 5 & 2.80 \\
France & 28.1 & 4 & 50 & 0.80 \\
Germany & 26.6 & 4 & 3 & 1.85 \\
Hungary & 36.4 & 3 & 3 & 2.37 \\
Ireland & 31.5 & 3 & 5 & 2.60 \\
Italy & 28.2 & 4 & 17 & 0.98 \\
Lithuania & 34.0 & 3 & 10 & 1.04 \\
Luxembourg & 42.7 & 3 & 3 & 8.55 \\
Poland & 24.3 & 7 & 15 & 1.03 \\
Portugal & 36.8 & 3 & 3 & 1.27 \\
Slovenia & 33.9 & 4 & 3 & 3.24 \\
Spain & 24.0 & 4 & 23 & 1.09 \\
Sweden & 24.6 & 5 & 39 & 1.02 \\
The Netherlands & 19.7 & 3 & 71 & 1.86 \\
United Kingdom & 27.5 & 4 & 21 & 1.01 \\
\hline
\end{tabular}

\footnotetext{
${ }^{8}$ Armstrong (2002), Vogelsang (2003), and Calzada and Trillas (2005) review the literature on interconnection.

${ }^{9}$ Commission Recommendation 2009/396/EC of 7 May 2009 on the Regulatory Treatment of Fixed and Mobile Termination Charges in the EU. For an analysis of the effects of MTRs on mobile operators' prices see Genakos and Valletti (2015).
} 
The results of the estimation made with these new variables are shown in Table 8. For the sake of simplicity, the new regressions do not distinguish between 12- and 24-month plans and do not include the results for Penalties. The results for the Speed, Volume, Limited Data, Limited Voice Minutes and Smartphone variables are similar to those presented in Table 6, and suggest that the pricing structure used by European operators is similar to that described previously. One difference is that the dummies for iPhone and Samsung are now positive and significant in all specifications.

If we focus on the variables reflecting competition intensity, we observe that the $H H I$ is always positive and significant in specifications 1 to 4 . The coefficient of this variable when using 2SLS-IV in specification 3 shows that a reduction in the $H H I$ of about 1 point generates a price reduction of 5.5\%. For example, in the period analyzed, there was a 1 point reduction in the $H H I$ in the UK, which should imply a price reduction of 5.5\%, ceteris paribus. This result points to the effect of market competition on broadband prices, complementing the recent results of Genakos et al. (2015) when studying the impact of market structure on the prices of voice services in the EU in the period 2002-2014.

The $M V N O$ variable is negative and significant in specifications 5 and 6 but not in specification 4, possibly because of the high correlation with the $H H I$. The findings for this variable indicate that the entry of an additional MVNO into the market decreases the prices of the plans by up to $2 \%$. Thus, although MVNOs need to reach agreements with MNOs in order to provide the services, their presence increases competition and pushes prices down.

Finally, the MTR variable is not significant in any specification, which suggests that in the period considered the regulation of termination charges does not explain the differences in broadband prices. Various factors can help us understand this result. First, notice that most European regulators drastically reduced termination fees after the 2009 EU Recommendation, which in turn has significantly lowered operators' off-net call costs. Second, due to the increase in data traffic, the overall weight of termination fees in operators' costs is smaller. And third, in line with the explanation offered by Genakos and Valletti (2015), in recent years there has been a significant but declining waterbed effect of MTR on the prices of mobile voice services. This change would appear to be related to the increase in mobile voice traffic from fixed to mobile phones. 
Table 8: Estimation Results: Mobile Broadband and Voice on Smartphone: Plans EU-20.

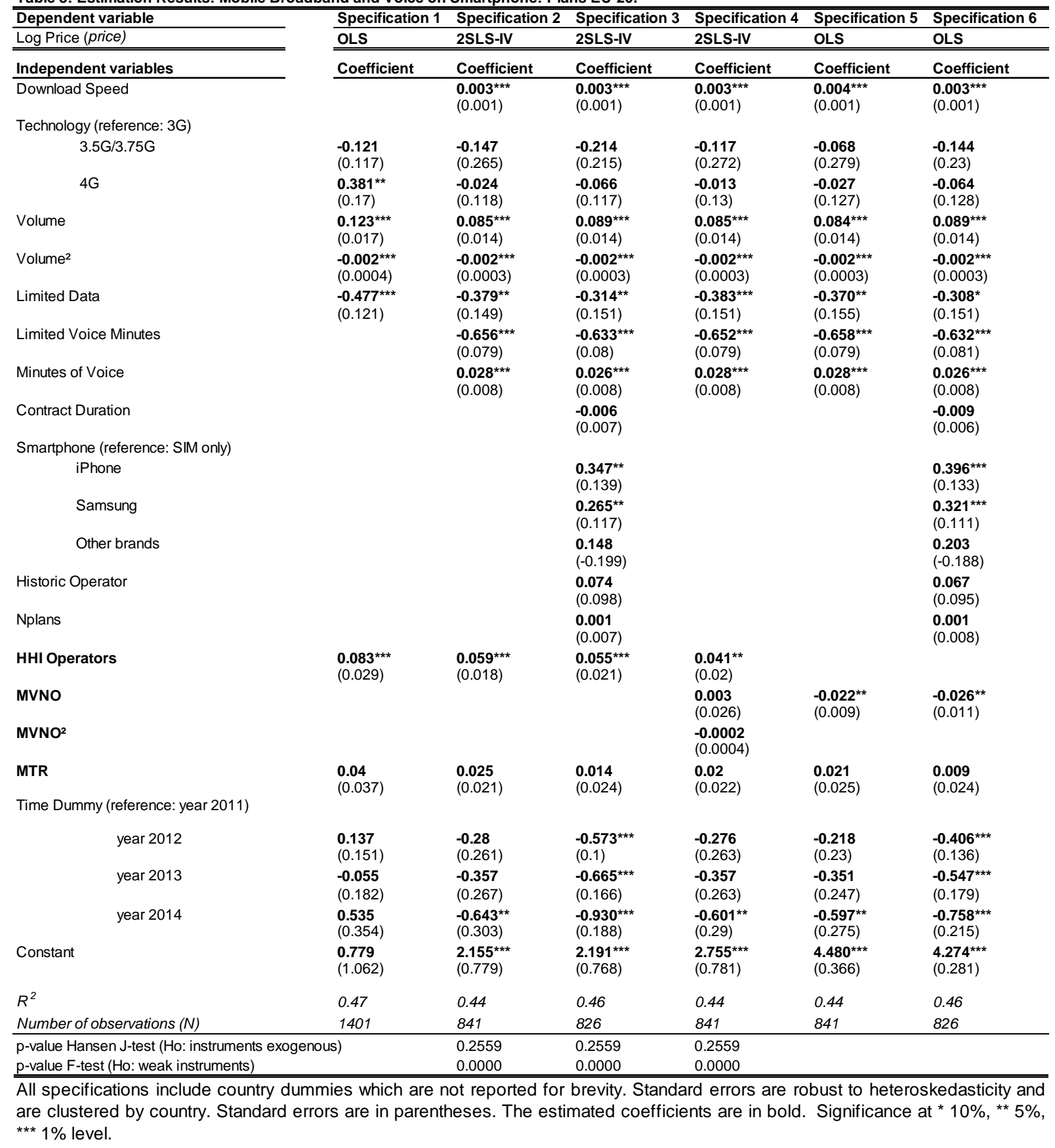

\section{Conclusions}

This paper has used a rich dataset of smartphone broadband plans from 37 countries to study the pricing structure of mobile operators in the period 2011-2014. The main contribution has been to show how usage-based plans use data and voice minute allowances to segment customers according to their needs (second degree price discrimination). The plans also include penalties that consumers who exceed the contracted volume allowances must face. We have identified the 
impact that volume allowance caps and penalties have on the monthly price of the broadband service.

In contrast to the situation in the fixed telephony market, the download speed plays a small role in the mobile operators' tariff structure. It might be the case that the technological limitations of wireless communications make mobile operators less able to differentiate their plans in terms of download speed. The technology used in providing the service also has little impact on prices. During the first stages of the transition from $3 \mathrm{G}$ to $4 \mathrm{G}$, operators commercialized $4 \mathrm{G}$ plans as a premium service. However, when we consider the whole period 2011-2014 we obtain little evidence that $4 \mathrm{G}$ affects prices via channels other than that of the download speed.

Most plans include voice minute allowances, which are usually quite high. The pricing structure of the voice service is similar to that of the broadband service, i.e., consumers choose voice minute allowances and pay an extra fee if they exceed the cap. Many plans offer unlimited voice, but at a significantly higher price. Interestingly, broadband plans no longer distinguish between on-net and off-net calls, or between mobile-to-mobile and mobile-to-fixed calls.

The paper's second most significant contribution has been to explain how operators modify their prices when they bundle the broadband service with a smartphone. Operators offer smartphones at a discounted rate but they partly subsidize this cost via higher prices for the broadband service. They also distribute the cost of the device over the duration of the contract, thus tying consumers for longer periods. We have also shown that broadband service prices vary depending on the smartphone brand bundled in the plan (third degree price discrimination). While plans that include iPhone and Samsung smartphones are more expensive than SIM-only plans, those that bundle other brands do not present a significant price difference with respect to SIM-only plans.

The last part of the paper has examined the pricing policies of mobile operators in $20 \mathrm{EU}$ countries for which we have additional information capturing the market structure and the regulation. We have found that market concentration and the number of MVNOs have a significant effect on broadband prices. By contrast, the regulation of MTRs does not appear to drive broadband prices. This may well be the result of the application of the "glide path" mechanism in the EU and the decreasing weight of off-net calls in the operators' costs.

A recent trend in the sector, though one not considered here, is the bundling of fixed and mobile voice and data services, along with the possibility of obtaining pay-per-view TV. ${ }^{10}$ Such plans have become very popular as they help households control their expenditure and they may represent major cost savings. In some countries, the popularization of these plans has forced the restructuring of the market toward platform-converged market operators that provide all core communications services. In the years to come it will be imperative to study the effects of these changes on operators' pricing strategies.

\footnotetext{
${ }^{10}$ Grzybowski and Liang (2014) estimate demand for quadruple play mobile tariffs. See also Vogelsang (2010).
} 


\section{Appendix}

Annex 1: Average discounts (\$PPP) on smartphone when bundled with tariff by country.

\begin{tabular}{|c|c|c|c|c|}
\hline & Plans & iPhone & Samsung & Other brands \\
\hline Australia & 0 & - & - & - \\
\hline Austria & 0 & - & - & - \\
\hline Belgium & 17 & 335.9 & 327.2 & - \\
\hline Brazil & 0 & - & - & - \\
\hline Bulgaria & 0 & - & - & - \\
\hline Canada & 32 & 374.5 & 253.5 & - \\
\hline Chile & 3 & 726.8 & - & - \\
\hline Czech Republic & 10 & 198.8 & 177.0 & - \\
\hline Denmark & 4 & 154.0 & - & - \\
\hline Estonia & 9 & - & 149.4 & - \\
\hline Finland & 0 & - & - & - \\
\hline France & 51 & 343.0 & 156.9 & - \\
\hline Germany & 36 & 547.2 & 459.7 & - \\
\hline Greece & - & - & - & - \\
\hline Hong Kong & 12 & 589.9 & 394.2 & - \\
\hline Hungary & 20 & 604.5 & 681.7 & - \\
\hline Iceland & 23 & 92.3 & - & - \\
\hline India & 9 & 64.0 & - & 231.5 \\
\hline Ireland & 68 & 440.6 & 589.1 & 371.9 \\
\hline Israel & 1 & - & 179.5 & - \\
\hline Italy & 6 & 591.3 & - & - \\
\hline Japan & 7 & - & 479.2 & - \\
\hline Korea & 13 & 107.5 & - & - \\
\hline Lithuania & 16 & 1247.4 & 389.3 & 212.6 \\
\hline Luxembourg & 2 & - & 527.6 & 275.7 \\
\hline Mexico & 5 & 1019.3 & 891.5 & - \\
\hline New Zealand & 22 & 219.0 & 136.0 & - \\
\hline Norway & 22 & 388.0 & - & - \\
\hline Poland & 5 & 534.1 & 754.2 & - \\
\hline Portugal & 9 & 16.4 & - & - \\
\hline Singapore & 4 & - & 572.0 & - \\
\hline Slovakia & 7 & 531.6 & 201.7 & - \\
\hline Slovenia & 19 & 189.9 & - & - \\
\hline Spain & 14 & 225.0 & - & - \\
\hline Sweden & 12 & 563.4 & - & - \\
\hline Switzerland & 41 & 166.9 & 305.3 & 77.5 \\
\hline The Netherlands & 36 & 452.1 & 290.4 & - \\
\hline Turkey & - & - & - & - \\
\hline United Kingdom & 25 & 439.5 & 413.2 & 385.2 \\
\hline United States & 136 & 451.8 & 407.8 & - \\
\hline Total & 696 & 358.2 & 391.1 & 327.0 \\
\hline
\end{tabular}


Annex 2: Estimation Results: Pass-through of discount on smartphone to the price of the plan.

\begin{tabular}{|c|c|c|c|c|}
\hline Dependent variable & Specification 1 & Specification 2 & Specification 3 & Specification 4 \\
\hline Log Price (price) & OLS & OLS & OLS & OLS \\
\hline Independent variables & Coefficient & Coefficient & Coefficient & Coefficient \\
\hline Discount & $\begin{array}{l}\mathbf{0 . 1 2 4} \\
(0.107)\end{array}$ & $\begin{array}{l}\mathbf{0 . 1 7 4}{ }^{\star} \\
(0.087)\end{array}$ & $\begin{array}{l}\mathbf{0 . 2 9 9 * * *} \\
(0.099)\end{array}$ & $\begin{array}{l}\mathbf{0 . 2 8 4}^{\star \star \star} \\
(0.077)\end{array}$ \\
\hline Download Speed & & $\begin{array}{l}\mathbf{0 . 0 0 1} \\
(0.002)\end{array}$ & & $\begin{array}{l}\mathbf{0 . 0 0 5} 5^{\star \star *} \\
(0.002)\end{array}$ \\
\hline \multicolumn{5}{|l|}{ Technology (reference: 3G) } \\
\hline $3.5 \mathrm{G} / 3.75 \mathrm{G}$ & n/a & n/a & n/a & n/a \\
\hline $4 G$ & $\begin{array}{l}\mathbf{0 . 1 3 2} \\
(0.126)\end{array}$ & $\begin{array}{l}\mathbf{0 . 0 1 8} \\
(0.2)\end{array}$ & $\begin{array}{l}\mathbf{0 . 0 4 3} \\
(0.157)\end{array}$ & $\begin{array}{l}-0.295 \\
(0.235)\end{array}$ \\
\hline Volume & $\begin{array}{l}\mathbf{0 . 1 1 4} \\
(0.013)\end{array}$ & $\begin{array}{l}\mathbf{0 . 1 1 6 * \star \star} \\
(0.012)\end{array}$ & $\begin{array}{l}\mathbf{0 . 1 2 9 * \star *} \\
(0.009)\end{array}$ & $\begin{array}{l}\mathbf{0 . 1 2 9 * * *} \\
(0.007)\end{array}$ \\
\hline Volume $^{2}$ & $\begin{array}{l}-0.002^{\star * *} \\
(0.0002)\end{array}$ & $\begin{array}{l}-0.002^{\star \star \star} \\
(0.0003)\end{array}$ & $\begin{array}{l}-0.003^{\star \star \star} \\
(0.0002)\end{array}$ & $\begin{array}{l}-0.003^{\star \star \star} \\
(0.0003)\end{array}$ \\
\hline Limited Data & $\begin{array}{l}-0.15 \\
(0.251)\end{array}$ & $\begin{array}{l}-0.734^{\star \star *} \\
(0.122)\end{array}$ & $\begin{array}{l}-0.415^{*} \\
(0.223)\end{array}$ & $\begin{array}{l}-0.878^{* * *} \\
(0.111)\end{array}$ \\
\hline Limited Voice Minutes & $\begin{array}{l}-0.415^{\star \star *} \\
(0.094)\end{array}$ & $\begin{array}{l}-0.529 * \star \star \\
(0.088)\end{array}$ & $\begin{array}{l}-0.333^{\star *} \\
(0.12)\end{array}$ & $\begin{array}{l}-0.495^{\star \star *} \\
(0.126)\end{array}$ \\
\hline Minutes of Voice & $\begin{array}{l}\mathbf{0 . 0 1 8}^{\star \star} \\
(0.008)\end{array}$ & $\begin{array}{l}\mathbf{0 . 0 3 5 * \star *} \\
(0.011)\end{array}$ & $\begin{array}{l}\mathbf{0 . 0 0 6} \\
(0.007)\end{array}$ & $\begin{array}{l}\mathbf{0 . 0 3 6 * *} \\
(0.013)\end{array}$ \\
\hline \multicolumn{5}{|l|}{ Smartphone (reference: iPhone) } \\
\hline Samsung & & $\begin{array}{l}-0.07 \\
(0.068)\end{array}$ & & $\begin{array}{l}\mathbf{0 . 1 0 5} \\
(0.077)\end{array}$ \\
\hline Other brands & & $\begin{array}{l}-\mathbf{0 . 1 6 7} \\
(0.115)\end{array}$ & & $\begin{array}{l}-0.169 * * * \\
(0.058)\end{array}$ \\
\hline Historic Operator & & $\begin{array}{l}\mathbf{0 . 0 8 5} \\
(0.078)\end{array}$ & & $\begin{array}{l}\mathbf{0 . 1 2 8 *}^{*} \\
(0.063)\end{array}$ \\
\hline Constant & $\begin{array}{l}1.416^{* *} \\
(0.544)\end{array}$ & $\begin{array}{l}1.511^{\star * *} \\
(0.539)\end{array}$ & $\begin{array}{l}1.877^{\star \star \star *} \\
(0.608)\end{array}$ & $\begin{array}{l}1.028^{*} \\
(0.574)\end{array}$ \\
\hline$R^{2}$ & 0.62 & 0.71 & 0.82 & 0.77 \\
\hline Number of observations ( $N$ ) & 639 & 518 & 440 & 359 \\
\hline
\end{tabular}




\section{References}

Armstrong, M. (2002). The theory of access pricing and interconnection, Handbook of Telecommunications Economics, Vol. I, Elsevier: Amsterdam, 297-384.

Ascarza, E., Lambrecht, A., \& Vilcassim, N. (2015). When Talk is "Free": An Analysis of Subscriber Behavior under Two- and Three-Part Tariffs, Journal of Marketing Research, 49 (6), 882-899.

Bacache, M., Bourreaum M., \& Gaudin, G. (2014). Dynamic Entry and Investment in New Infrastructures: Empirical Evidence from the Fixed Broadband Industry, Review of Industrial Organisations, forthcoming, 44 (1), 179-209.

Baumol, W. (2005). Regulation Misled by Misread Theory: Perfect Competition and Competition-Imposed Price Discrimination, AEI-Brookings Joint Center for Regulatory Studies.

Bouckaert, J., Van Dijk, T., \& Verboven, F. (2010). Access regulation, competition, and broadband penetration: An international study, Telecommunications Policy, 34, 661-671.

Briglauer, W., Ecker. G., \& Gugler, K. (2013). The impact of infrastructure and service-based competition on the development of next generation access networks: recent evidence from the European member states, Information Economics and Policy, 25, 142-153.

Calzada, J., \& Martínez-Santos, F. (2014a). Broadband prices in the European Union: Competition and commercial strategies, Information Economics and Policy, 7, 24-38.

Calzada, J., \& Martínez-Santos, F. (2014b). Competencia en el Mercado de banda ancha móvil en España, Cuadernos Económicos del ICE, 88, 97-129.

Calzada, J., \& Trillas, F. (2006). Los precios de precios de interconexión en las telecomunicaciones: de la teoría a la práctica, Hacienda Pública Española, Vol. 173, 2, 85-125.

Cambini, C., \& Jiang, Y. (2009). Broadband Investment and Regulation: A literature Review, Telecommunications Policy, 33 (10-11), 559-574.

Economides, N., \& Hermalin, B.E. (2015). The Strategic Use of Download Limits by a Monopoly Platform, Rand Journal of Economics, 46, 2, 297-327.

European Commission (2011). Broadband Internet Access Costs (BIAC). Final Report, Information Society and Media Directorate-General.Van Dijk - Management Consulting.

FCC (2015). Fourth International Broadband Data Report, Federal Communications Commission, Washington.

Gabaix, X,. \& Laibson, D. (2006). Shrouded attributes, consumers myopia, and information suppression in competitive markets, Quarterly Journal of Economics, 121 (2), 505-540. 
Genakos, C., \& Valletti, T. (2015). Evaluating a decade of mobile termination rate regulation, Economic Journal, 125 (586), F31-F48.

Genakos, C., Valletti, T. \& Verboven, F. (2015). Evaluating Market Consolidation in Mobile Communications, Centre on Regulation in Europe, CERRE.

Garin-Muñoz, T., Perez-Amaral, T., Gijón, C., \& Lopez, R. (2015). Consumer complaint behavior in telecommunications: The case of mobile phone users in Spain, Telecommunications Policy, forthcoming

Gijon, C., Garin-Muñoz, T., Perez-Amaral, T., \& Lopez-Zorzano, R. (2013). Satisfaction of individual mobile phone users in Spain, Telecommunications Policy, Volume 37, Issue 10, November 2013, 940-954.

Grajek, M., \& Röller, L.-H. (2012). Regulation and investment in network industries: Evidence from European telecoms, Journal of Law and Economics, 55 (1): 189-216.

Greenstein, S., \& McDevitt, R. (2011). Evidence of a modest price decline in US broadband services, Information, Economics and Policy, 23 (2), 200-211.

Gruber, H., \& Koutroumpis, P. (2013). Competition enhancing regulation and diffusion of innovation: the case of broadband networks, Journal of Regulatory Economics, 43: 168-195.

Grzybowski, L., \& Dauvin, M. (2014). Estimating broadband diffusion in the EU using NUTS1 regional data, Telecommunications Policy, 38(1), 96-104.

Grzybowski, L., \& Liang, J. (2014). Estimating demand for quadruple-pay tariffs: The impact on consumer surplus, mimeo.

Halvorsen, R., \& Palmquist, R. (1980). The Interpretation of Dummy Variables in Semilogarithmic Equations, The American Economic Review, Vol. 70, No. 3, 474-475.

Haucap, J., Heimeshoff, U., \& Lange, M. (2014). The impact of tariff diversity on broadband diffusion: An empirical analysis, DICE Discussion Paper, No. 156.

Hoernig, S. (2001). Collusion and confusion?, mimeo.

Lambrecht, A., Seim, K., \& Skiera, B. (2007), Does Uncertainty Matter? Consumer Behavior under Three-Part Tariffs, Marketing Science, 26 (5), 698-710.

Lee, S., Marcu, M., \& Lee, S. (2011). An Empirical analysis of fixed and mobile broadband diffusion, Information Economics and Policy, 23, 227-233.

Leider, S., \& Sahin, O. (2015). Contracts, biases and consumption of access services, mimeo. 
Lyons, D. (2013). Internet Policy's Next Frontier: Data Caps, Tiered Service Plans, and Usage Broadband Pricing, Federal Communications Law Journal, 66, 1, 1-44.

Miravete, E. (2003). Choosing the Wrong Calling Plan? Ignorance and Learning. American Economic Review, 93(1): 297-310.

Miravete, E., \& I. Palacios-Huerta (2014). Consumer inertia, choice dependence and learning from experience in a repeated decision problem, Review of Economics and Statistics, 96 (3), 524-537.

Nardotto, M., Valletti, T., \& Verboven, F. (2015). Unbundling the Incumbent: Evidence from UK broadband, Journal of the European Economic Association, vol. 13, n. 2, 330-362.

Nevo, A., Turner, J.L., \& J. Williams, J. (2016). Usage-Based Pricing and Demad for Residential Broadband, Econometrica, vol. 84 (2), 411-443.

Pereira, P., \& Ribeiro, T. (2010). The impact on broadband access to the Internet of the dual ownership of telephone and cable networks, International Journal of Industrial Organizations, 29, 283-293.

Sinkinson, M. (2014). Pricing and Entry Incentives with Exclusive Contracts: Evidence from Smartphones, mimeo.

Srinuan, C., Srinuan, P., \& Bohlin, E. (2012a). An analysis of mobile Internet access in Thailand: Implications for bridging the digital divide. Telematics and Informatics, 29, 254-262.

Srinuan, C., Srinuan, P. \& Bohlin, E. (2012b). Fixed and mobile broadband substitution in Sweden. Telecommunications Policy, 36(3), 237-251.

Srinuan, C., Srinuan, P. \& Bohlin, E. (2013). Pricing strategies and innovations in the Thai mobile communications market, Info, 15 (1), 61 - 77.

Tirole, J. (1988). The Theory of Industrial Organisations, Cambridge, MA: The MIT Press.

Vogelsang, I. (2003). Price Regulation of access to telecommunications networks, Journal of Economic Literature, 41 (3).

Vogelsang, I. (2010). The Relationship between mobile and fixed-line communications: a survey, Information Economics and Policy, 22(1): 4-17.

Wallsten, S., \& Riso, J.L. (2010). Residential and Business Broadband Prices: Part 1: An Empirical Analysis of Metering and Other Price Determinants, Technology Policy Institute.

Westlund, O,. \& Bohlin, E. (2008). Explaining Mobile Internet Adoption and Use: Results from a National Survey in Sweden. Paper presented at the 17th Biennial ITS Conference, Montreal, Canada, June 24-27, 2008. 
Wilson, R. (1993), Nonlinear pricing. New York: Oxford University Press.

Zhu, T., Liu, H., \& Chintagunta, P. (2015). Wireless Carriers' Exclusive Handset Arrangements: An Empirical Look at the iPhone, Customer Needs and Solutions, 2, 177-190. 